\title{
forestry news
}

\section{People on the Move}

A. O. Aschim, Assistant Supervisor fire control Saskatchewan Department of Natural Resources has retired after 33 years of public service.

Hon. Jack Davis, Minister of Fisheries and Forestry, today announced that the Public Service Commission has appointed Dr. R. M. Belyae as Director of Operations for the Canadian Forestry Service. Dr. Belyea, 49, was formerly Regional Director for Ontario, based at Sault Ste. Marie. As Director of Operations he will be assuming a new position at the senior management level at the Canadian Forestry Service headquarters in Ottawa. Dr. Belyea joined the federal public service as a research officer in 1946, and received his PhD. in Forest Entomology from the University of

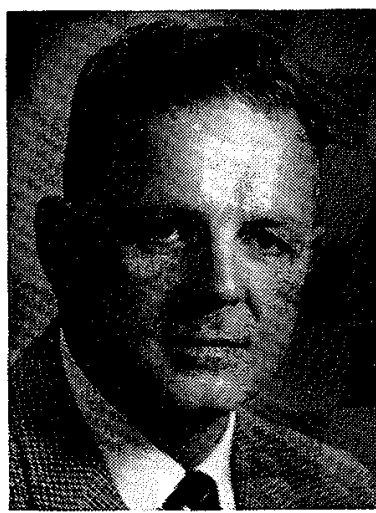

Dr. R. M. Belyae

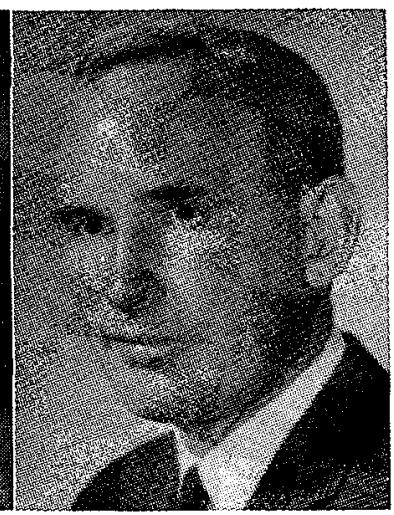

A. A. Boyle

Toronto in 1951. From 1952 to 1960 he was in charge of the Forest Insect Laboratory at Sault Ste. Marie, and from 1960 to 1965 was Officer-in-charge of the Forest Biology Laboratory at Fredericton, N.B. He was appointed Director of the Department's Regional establishment at Sault Ste. Marie in 1965.

\section{R. J. Burgar}

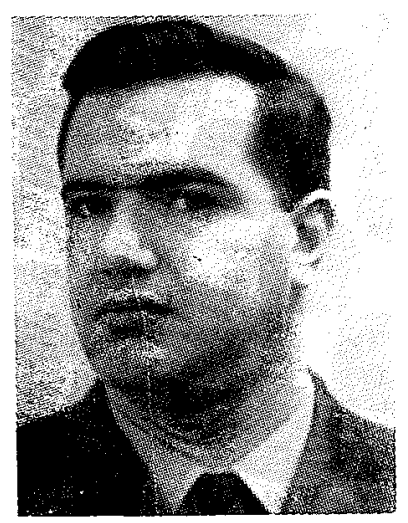

A. A. Boyle has been appointed Sales Manager, Woodiands Equipment for Koehring Waterous Ltd. in Brantford, Ontario. Mr. Boyle will be responsible for sales of the Koehring Harvester, Forwarder and Pulpwood Load Aligner and will work with the company's engineering group to continue development of pulpwood harvesting machinery.

R. J. Burgar has been appointed District Forester, Dept. of Lands and Forests, Cochrane, Ontario.

Don Fraser from the Petawawa Forest Expt. Station, Chalk River, has returned from his 2-month trip to the U.S.S.R. where he was an exchange scientist of the Canada National Research Council and the U.S.S.R. Academy of 
Sciences. While in the Soviet Union, Don has visited mainly laboratories concerned with the physiology of flower induction.

S. A. Fournier has been appointed General Superintendent, Noranda Division, Canadian International Paper Co.

T. R. Hubbard, Management forester in the British Columbia Forest Service, Nelson, has been appointed forester-in-charge of the management division in the Vancouver Forest District. He succeeds W. G. Bishop, who has been promoted to the position of assistant district forester, Prince George.
T. R. Hubbard

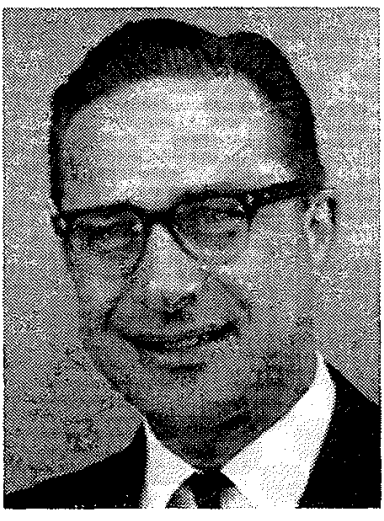

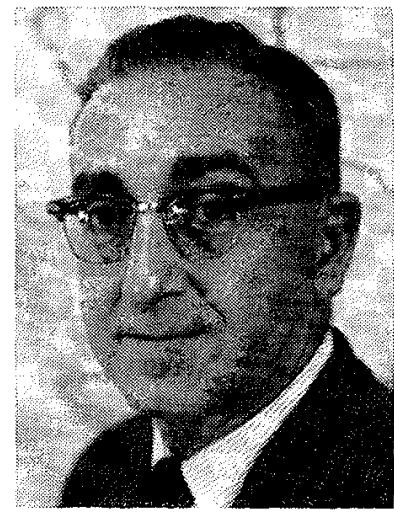

R. R. Lejeune
R. R. Lejeune, director of the federal Forest Research Laboratory at Victoria, B. C., has been transferred to Ottawa to become forestry member of a task force which is to make a thorough review of the organization of renewable resource research within the ministry of Fisheries and Forestry. The task force is being assembled by Dr. J. R. Weir, whose appointment as advisor on renewable resource development to the Minister of Fisheries and Forestry was announced recently.

Dr. G. P. Thomas, will succeed Mr. Lejeune as Director of the Victoria B. C. Forest Research Laboratory. For the past four years he has been director of the federal forestry research program in Alberta and the Northwest Territories, with headquarters in Calgary. M. H. Drinkwater, associate director of the Calgary Forest Research Laboratory since 1965, has been named acting director of that laboratory. A forestry graduate of the University of New Brunswick, he worked in the Department's Maritime Region from 1948 until 1960, when he was transferred to Alberta.

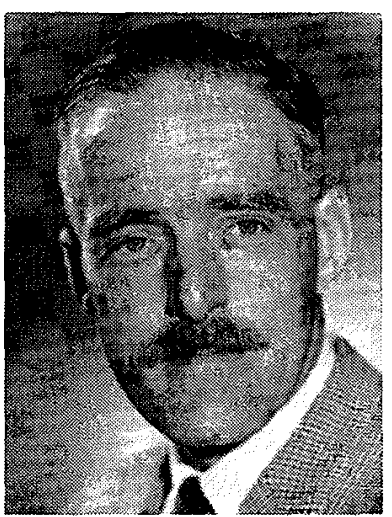

Dr. G. P. Thomas

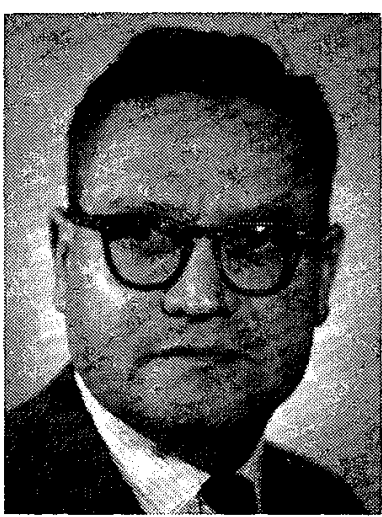

M. H. Drinkwater
George K. Ross, born in Scotland and 1958 BScF graduate from the University of Edinburgh has joined the CPPA Woodlands Section as director of the newly created Forest Management Group.

M. J. Rouse was appointed Planning Manager, Domtar Woodlands Ltd., Montreal.

Larry Scales, Farm Forester and Bill Collins, Management Forester of the Ontario Department of Lands and Forests, Pembroke and Dacre respectively, have joined the Staff of the Upper Ottawa Valley Campus of Algonquin College, in Pembroke, as of August 1. They will be responsible for the teaching and development of the newly established 2-year forestry technician course which started September 2.

Robert M. Schmon has been elected to the Board of Directors of Tribune Company at the company's annual meeting. He is President of The Ontario Paper Company Limited, Thorold Ontario; Quebec North Shore Paper Company, Baie Comeau, Quebec; and associated companies.

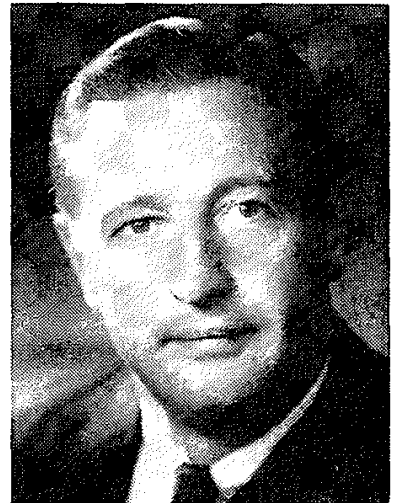

R. M. Schmon

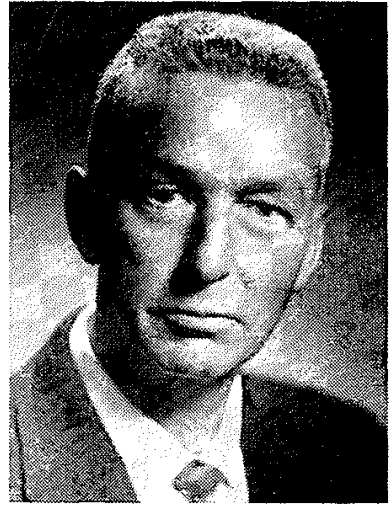

Victor V. Vaughan

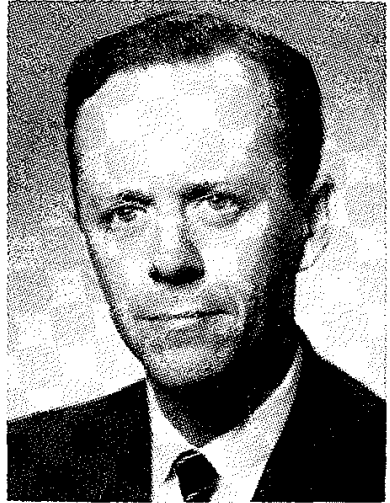

George K. Ross

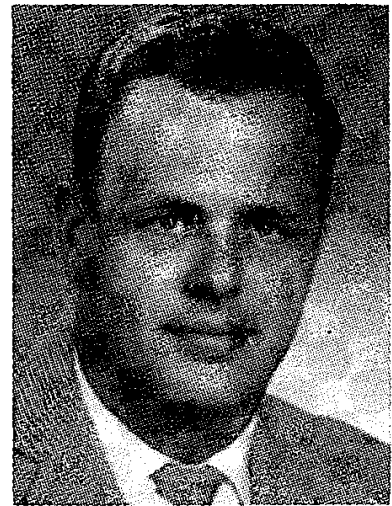

J. R. Wells
J. R. Wells was appointed District Logging Superintendent, Abitibi Paper Company, Lakehead Woodlands Division.

Dr. R. W. Wellwood, University of B. C. has been elected vice-president of the Forest Products Research Society. He is the first Canadian to be elected to the executive of this organization, the 4000 members of which represent more than 50 countries.

Victor $\mathbf{H}$. Vaughan has been appointed Logging Manager for Tahsis Company Ltd. after four years at the firm's chief logging engineer. Mr. Vaughan, a graduate of the University of B. C. has worked in the West Coast forest industry for 21 years. 
L. A. Smithers, 48, Associate Director of the Ontario Region, Department of Fisheries and Forestry, has been named Acting Director. A graduate of the University of New Brunswick, Mr. Smithers received his M. Sc. from the University of Toronto in 1947. He joined the Department in 1947.

George R. Sonley, Chief Forester of American Can of Canada Ltd. has retired. He graduated with a BScF from University of Toronto in 1930 and after a period of teaching and working for the civil service in Ottawa joined Marathon Corporation (now American Can) in 1945 where he stayed with the Woodlands Department until retirement.

M. Vezina has been appointed Assistant Deputy Minister and director of the Conservation Branch of the Department of Lands and Forests, Quebec.

\section{Why Slash Burning?}

Any day now - and for short periods - smoke will rise from various logging areas of our province.

It will come from an operation we refer to as "slash burning". Most people know the expression, but many, I feel, probably don't know HOW it is done. And more important, WHY it is done.

In basic terms, "slash burning" is the act of purposely setting fire to logged-off areas. It is a "science". It has to be done at precisely the right time, with wind, humidity, and other weather conditions in mind. And the job has to be done by highly trained and well qualified men.

These "slash burn" fires, as the very name indicates, are designed to get rid of branches, snags, unmerchantable logs, and all other unuseable material left in the wake of a logging operation.

Most logging operations today are being conducted in decadent and old growth timber stands with varying degrees of decayed wood, which cannot be used for any practical purpose.

A good "burn" will get rid of this useless material, without harming the soil.

Of course there is some understandable objection to smoke caused by slash burns. The Forest Service and the forest industries don't like it either... but at the present time, there appears to be no alternative.

Some people link slash burn smoke with the air pollution problem, usually just because it can be seen. Experts in the field admit the contribution of slash fire smoke to the overall problem is almost infinitesimal when compared to the invisible fumes coming from exhaust pipes of vehicular traffic.

And it is interesting to note the need for slash burning has been so evident that this activity has been exempted from air pollution controls in Washington and Oregon.

If anyone comes up with a better, more practical and economical method of disposing of logging slash, we will welcome him with open arms.

I am happy to say that, generally speaking, the Council of Forest Industries agrees with the current policy relating to slash burning. The Council represents more than 100 companies, large and small, which produce 85 per cent of the forest products of this province.
Let's look at the "why" question.

The reasons for slash burning are many and varied - and here are some of them:

Slash burning can be controlled - in both intensity and in area covered. Such operations are conducted by trained and qualified men of either the Forest Service and/or industry, during a relatively short period, late in the summer or early fall - when proper weather conditions prevail.

If logged-over areas are not subject to controlled burning, inevitably lightning, human carelessness or other causes will ignite them - presenting far greater blazes, endangering surrounding areas (and quite possibly human lives), and creating tremendously greater smoke problems.

And don't forget that fighting forest fires is an expensive business - an expensive business paid for by the people of British Columbia.

Slash burning paves the way for faster, more efficient and more productive reforestation measures. Seedlings can be planted easier and faster. They will grow quicker and straighter not having to fight their way through a tangle of snags, branches and other suffocating debris. They will have a head start and better survival chance in growth competition with bush and other non-useable tree species.

Slash burning practically eliminates any insect hazard which could be extremely harmful to adjacent timber.

So let's be realistic. The slightly "bad" aspect of slash burning - in the opinion of some - namely creation of smoke, is far outweighed by its benefits. Research has proved this.

It is the only practical and economical method we know of to date to dispose of residue after logging.

It is hoped, of course, the day will come when it will be economically feasible to use all material now classified as slash. This objective is a major part of our close utilization policy - introduced recently and already making significant progress.

Until this policy is in full effect throughout the province, the burning of slash in some areas will have to be continued.

Let us remember if such fires are not started and controlled by man, sooner or later they invariably will be started by some other means.

And to paraphrase and old proverb: an ounce of smoke today is better than a ton of smoke, trouble and expense tomorrow.

\section{British Columbia Forest Service}

\section{Camille Damage}

Hurricane Camille destroyed large numbers of trees and presented a potential area of bark beetle and disease attack. 6000 square miles of forest land in Mississippi and Louisiana were affected. USDA forestry officials met with state foresters in August to discuss the threat to some $\$ 500$ million in pine forests. It is believed that International Paper Co., St. Regis Paper Co., and Crown Zellerbach Corp. lands as well as state forests sustained damage.

Globe and Mail Business 


\section{Pollution - New Water Act}

The proposed new Canada Water Act, announced by the government, is designed to break through "the bureaucratic and jurisdictional maze" that has up to now bedevilled efforts at water pollution control and conservation, Otto Lang, Minister responsible for energy and water resources, said today.

"The Canadian public has become increasingly impatient with the failure to develop long-term plans and with the failure of the several levels of government to act in concert. The federal government has the responsibility to take the lead in cooperative action to deal with the growing problem of water pollution and to plan effectively for the management of Canada's water resources in the future", Mr. Lang said. "It is almost inconceivable", he said, "that cooperation would not be secured in dealing with a problem of such public concern. However, in such an unlikely eventuality the proposed act would give the federal government authority to act alone in dealing with the pollution of inter-jurisdictional waters".

Mr. Lang said that although many undertakings in the water field had been successful, there had been an overemphasis on structural, piecemeal solutions. One of the innovations that would correct this situation would be the Water Quality Management Agencies, which would be responsible to both the federal and provincial governments and draw on the advice and knowledge of local people, municipalities and industry. Ratepayers, he added, would be more willing to authorize expenditures on municipal waste-treatment plants if they knew that other municipalities and private industry were doing their part. Planning would embrace whole regions and river basins.

Mr. Lang concluded by saying that he intended to meet, almost immediately, with his colleagues in the provincial governments to start discussions on the implications of the proposed act. He called on all interested parties, including industry and municipalities, to share their views with him.

\section{Highlights of the Canada Water Act}

- Together with the provinces, the federal government would designate as a water quality management area any body of water where there is significant national interest.

- Pollution of waters in such designated areas would be punishable by a fine of up to $\$ 5,000$ for each offence. Each day this pollution continued it would be regarded as a separate offence.

- Together with the provinces, or alone if necessary on interjurisdictional waters, the federal government would launch water quality management programs in designated problem areas. These programs would be administered by agencies which would recommend objectives of water quality and steps to achieve these objectives. Agencies would be charged with implenienting approved water quality management plans.

- Water quality management agencies would design and operate sewage treatment facilities, collecting charges for the treatment of wastes delivered to these facilities.

- Ottawa would enter into agreement with any province to establish intergovernmental committees or agencies to advise on water research, planning, management, and development, and to help coordinate and implement water policies and programs.

- Together with the provinces, the federal government would establish joint commissions, boards or other agencies to conduct water management programs. Such programs would be concerned with the supply, quality, distribution and other aspects of water - a comprehensive approach to multi-purpose water resource management.

Department of Energy, Mines and Resources

\section{Hydraulics Course}

The Louisiana Tech. Department of Agricultural Engineering will offer a two-day course on hydraulics on November 20 and 21, 1969, on the main campus at Louisiana Tech.

The course will start with a study of the fundamentals of hydraulics, followed by a study of components, circuits and operating practices.

Louisiana Tech. Agricultural Engineering staff members and professionals of the hydraulics industry will be course instructors.

For further details call or write the Agricultural Engineering Department, Louisiana Tech., Ruston, La. 71270. Phone 318-255-2976.

\section{Growth Regulation}

FREDERICTON, N. B. - Scientists with the Canadian Forestry Service, Department of Fisheries and Forestry, are conducting research on the development of techniques for regulating plant and tree growth. This is part of a study of naturally occurring plant growth substances.

Development of such techniques would have many uses such as: delaying flowering of horticultural plants to meet market requirements; delaying of bud-break of frost sensitive plants; holding back dormant nursery material, etc.

An interesting sidelight of this research has been the emergence of the idea of the possibility of regulating tree growth and thereby controlling insects like the spruce budworm. The budworm causes millions of dollars of damage to forests in the department's Maritimes Region.

Drs. D. C. Eidt and C. H. A. Little, forestry research scientists with the department's Forest Research Laboratory here, prepared a research paper 
entitled "Insect Control Through Induced HostInsect Asynchrony - A Progress Report".

Dr. Eidt presented the paper at the 19th annual meeting of the Entomolog:cal Society of Canada held jointly with the 106th annual meeting of the Entomological Society of Ontario at the University of Guelph. He is a member of the board of directors of the Canadian Society and chairman of its Committee on Common Names of Insects. Theme of the conference is "pollution".

The paper outlined experiments in which attempts were made to artificially delay budbreak in fir and spruce trees, thus eliminating the food supply of spruce budworm larvae. The early instar larvae of the spruce budworm break hibernation in early May, and first mine old needles of spruce and fir, but must have new foliage in order to survive. By retarding the opening of buds of fir and spruce trees, the larvae would be deprived of food. Since at epidemic levels food supply becomes the factor limiting populations, small larvae would be starved. The next year, he pointed out, foliage supply would revert to normal, but the spruce budworm population would be much lower.

Drs. Eidt and Little described experiments carried out with abscisic acid to delay budbreak. The substance occurs naturally in most plants and effectively retards, but does not inhibit growth. "Risk of toxicity to animals is slight and possibility of environmental pollution is virtually non-existent", they said. However, the chemical is expensive because an economical manufacturing process has not yet been devised. The greatest problem is there is no known way to effectively apply the substance so that penetration of plant tissues will be effected. Until such a time as this problem is solved, further work on abscisic acid has been discontinued by the team.

They also described their experiments with commercial growth retardants such as maleic hydrazide and chlorflurenol. These were tried, despite the fact they are not natural products, with the hope they would delay budbreak in budworm host trees. They are inexpensive, readily available, and are widely used to control growth of grass and shade trees. Preliminary experiments were inconclusive and investigation will continue.

"We are also interested in any new plant growth inhibitors that may be discovered", said Dr. Eidt. "We are currently interested in experimenting with a naturally-occurring inhibitor that has been suggesdte as a weed killer because of its affinity for rapidly growing immature plants." This suggests it may have an affinity for new shoots but not old foliage of budworm host trees.

Research into the nature of plant growth is being strongly supported in many parts of the world and there is a constant flow of literature. World researchers are optimistic that means for controlling growth in plants will continue to be found as their understanding of growth improves. Dr Eidt expressed confidence that these means could be adapted to insect control.

G. L. Miller

\section{Scholarships to Encourage} National Parks Development

The Department of Indian Affairs and Northern Development announced the awarding of nine $\$ 2,000.00$ National Parks Service of Canada scholarships.

The awards are part of a training program designed to fill the increasing need for specialized personnel to plan for and manage, Canada's 19 national parks. The scholarships, tenable at Canadian universities in 1969-70, are open to people engaged in studies concerning natural parks and outdoor recreation.

Canadian Council of Resource Ministers

\section{North American Forestry Commission}

The North American Forestry Commission, a United Nations agency composed of senior forestry officials of the United States, Mexico and Canada, met at Ottawa September 15 to 20

Sponsored by the UN's Food and Agriculture Organization, the Commission was established in 1959 to encourage discussion and co-operation on forestry problems of common concern to the member countries.

Included on the agenda for this fifth session of the Commission were consideration of forest inventory methods, multiple-use management of forest lands, forestry education and external aid in the form of multilateral and bilateral technical assistance programs. The Commission also heard reports on the activities of its working committees on forest insects and diseases, forest fire control, wildlife and outdoor recreation, tree improvement, and forest engineering.

The Canadian delegation was headed by Dr. A.W.H. Needler, Deputy Minister of Fisheries and Forestry, who also was Session chairman.

An international festival of forestry films and posters was held in conjunction with the Commission session.

This is the second occasion on which Canada has been host to the North American Forestry Commission; its second session was held at Ottawa in 1963. The Commission met at the Centennial Centre, in downtown Ottawa.

Department of Fisheries and Forestry

\section{Sixth World Forestry Congress}

The proceedings of the Congress in three volumes are available from the "Ministerio de Agricultura, Paseo de Infanta Isabel I, Madrid 7, Spain. The total cost is 3,638 pesetas, including postage. Duplicate orders should be made payable to the "Sexto Congresso Forestal Mundial". 


\section{New Deputy Ministers}

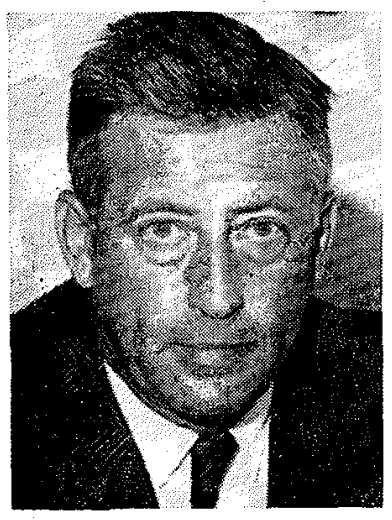

R. H. Burgess
Nova Scotia Lands and Forests Minister George A. Snow has announced the appointment of Robert Burgess as Deputy Minister of the Department. He succeeds Dr. G. W. I. Creighton who retired May 31.

Mr. Burgess joined the Department in 1947 as a district forester. He served as provincial forester from 1950 to 1959 when he was named Director of Forestry. In 1966 he was appointed Administrative Assistant to the Deputy Minister.

$\mathrm{He}$ was born at Shubenacadie and graduated from Colchester County Academy. He received a science degree in forestry from the University of New Brunswick.

During the Second World War he served overseas in the Canadian Forestry Corps. He was discharged as Captain in 1946, following which he was an instructor at Maritime Forest Ranger School in Fredericton, N.B., until joining the Department.

Mr. Burgess is a member of the Nova Scotia Provincial Land Surveyors Association and the Maritime Section of the Canadian Institute of Forestry.

(Windsor, N.S., Hants Journal.)

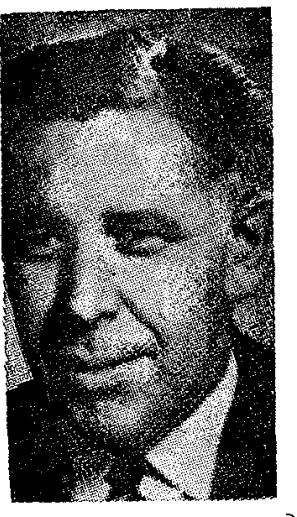

B.C. Minister of Lands, Forests and Water Resources, Ray Williston has announced the appointment of John $\mathbf{S}$. Stokes as Deputy Minister of Forests, succeeding F. S. Mckinnon who has retired.

John Stokes, who assumed his duties on August 1 , has had a prominent part in developing the recent forest policies of close utilization of wood.

Born in Victoria in 1913, he first entered the B.C. Forest Service on May 3, 1939. During the Second World War, he served with the Royal Canadian Air Force, returning to the Forest Service May 1, 1945, as a Ranger at Prince Rupert.

On April 1, 1946, he was promoted to Forester and in January of the following year, he was transferred to Vancouver, where he remained until his transfer on June 1, 1950, to Forest Service headquarters in Victoria.

$\mathrm{He}$ was appointed Forester-in-Charge of the Forest Management Division on April 1, 1952, and three years later became Assistant Chief Forester in charge of Management, a position he held until
July 1965, when he was named Assistant Chief Forester in charge of Operations for the B.C. Forest Service.

(Hiballer Magazine.)

\section{Manpower}

Victoria, B.C. - (July 18) - Development of the logging industry in the coastal region of British Columbia and a detailed look at the past, present and future manpower aspects of the industry are included in an informative booklet released this week by the Research Branch of the provincial Department of Labour.

Prepared by D. W. Ross, of the research organization, the 66-page booklet features detailed facts and statistics relating to the logging labour force; with interesting notes of the past, and projections into the future. A considerable portion of the booklet deals with past and present logging methods and techniques.

In its look into the future, the report embraces production and employment forecasts up to 1975. Its various tables present interesting figures on logging requirements, production, employment statistics, timber classifications, and other related subjects.

As a reference source, the booklet will be of significant interest to any person or firm engaged in the logging industry in the coastal region of the province.

Copies are available, free of charge, from the Research Branch, Department of Labour, Parliament Buildings, Victoria, B.C.

British Columbia Forest Service.

\section{Aerial Spraying a Success in Newfoundland}

In Newfoundland the eastern hemlock looper is the most serious defoliating insect on mature balsam fir and outbreaks occur at intervals of about 6 to 8 years. The most severe outbreak ever recorded began in 1966. By 1968 more than 800,000 acres were heavily infested and wood losses were estimated at 3,000,000 cords. In the same year the first aerial spraying operation in Newfoundland was conducted to protect about 400,000 acres of infested stands. Moth surveys in the fall indicated that the size of the outbreak would increase in 1969 and forest agencies recognized that continuation of severe damage was a major threat to the woods industry on the Island. A task force was formed with representation from the Newfoundland Forest Service, Bowaters Newfoundland Limited, Price (Nfld). Pulp and Paper Limited, and the Canadian Forestry Service to plan a chemical control operation.

The Canadian Forestry Service was responsible for biological aspects of the program including defining stand hazard characteristics, timing the operation, 
recommending spray dosages, establishing infestation boundaries, and appraising effectiveness of treatments. The other agencies were responsible for determining and adjusting priority areas based on stand susceptibility and economic value, and for co-ordinating the entire operation. More than 4,000,000 acres were considered within three priority classes with about $2,000,000$ being allocated to the highest class. Detection and appraisal surveys used three helicopters for sampling more than 700 locations. Forest Protection Limited of New Brunswick was responsible for aerial spraying and used 40 aircraft to treat about 2,000,000 acres with organophosphate insecticides, primarily Sumithion. Early in the operation the insecticide was applied at two ounces in each of two treatments per acre but as larval development progressed the concentration was increased by 50 per cent.

Results of post-spray sampling showed that about 95 per cent of the larvae were killed in most treated areas. Preliminary damage appraisal surveys show that very little tree mortality will occur in treated areas. However, severe damage and tree mortality is expected in several untreated stands. Sampling of adult populations is in progress and moths have been reported in high numbers in some areas. A forecast of outbreak conditions for 1970 cannot be made until surveys have been completed.

\section{G. L. Warren Canadian Forestry Service,} St. John's, Nfld.

\section{Second World Consultation On Forest Tree Breeding:}

FAO IUFRO and the United States Forest Service organized this Consultation which met at Washington, D. C., August 7-16 1969. The leading forest tree breeders, numbering 212 from 40 nations, participated in the technical meeting and the field trips that preceded and followed the Consultation. The theme of the Consultation, "Practical Advantages of Forest Tree Breeding" was developed in 14 halfday meetings, each devoted to a topic under the theme. Primary consideration was given to breeding for high-yielding characteristics and to the techniques for producing and using high-yielding varieties. A number of recommendations to international organizations, governments and scientists should stimulate and improve forest tree breeding activities in the future. About 58 people participated in field trips before the Consultation to the Northeast, Southeast and deep South regions of the United States. Following the Consultation, 50 people participated in field trips to the North Central and far Western portions of the United States. These field trips provided an excellent opportunity for participants to see the latest developments in research and action programs aimed at producing high-yield varieties of forest trees adapted to a wide variety of forest environments.

IUFRO Newsletter

\section{B. C. Fires}

A recent article in the Peace River Block News, Dawson Creek, B.C. announced that there had been 21,730 fires in B.C. forests in the last 10 years. These fires were said to have burned more than two and a half million acres destroying about two and a half million board feet of timber representing a potential payroll loss of $\$ 14$-million. Direct cost of fighting these fires was quoted as over $\$ 21$-million to the B.C. Forest Service and a similar amount to logging companies and other agencies.

In an appeal to the public the paper announced that 90 per cent of recent fires were caused by people, 70 per cent by campers and smokers and all of them preventable.

A September 5 news release from the British Columbia Forest Service reported 2,240 fires for the 1969 season and a total cost of firefighting operations of just over three million dollars.

\section{Resource Sciences Centre}

On July 1968, the University of British Columbia established a Resource Sciences Centre to stimulate and facilitate research and graduate training in the field of renewable resources. A five phase program was initiated: a sequence of graduate courses organized in renewable resources; fellowships for $\mathrm{Ph}$. D. students concerned with the interdisciplinary character of resource systems; an existing Ecology Computing Centre expanded to include all resource sciences; a Resource Science Workshop; and major interdisciplinary research foci for the study of water and land systems.

Further information can be obtained from Dr. C.S. Holling, Chairman, Resources Science Centre, Faculty of Graduate Studies, University of British Columbia, Vancouver, B.C.

Canadian Council of Resource Ministers

\section{Freshwater Research Institute}

The Canada Department of Fisheries and Forestry announced the construction of a research institute on the University of Manitoba campus. The Freshwater Institute will be directed towards fish farming, the improvement of existing fish stocks in the northern waters and water pollution control. The staff at Winnipeg's new Freshwater Institute will be responsible for studies on eutrophication in river systems as far apart as the Okanagan in British Columbia and the St. John River in New Brunswick.

The buildings containing the new Freshwater Institute are the first of a series in what will become a renewable resource complex. An initial staff of more than 340 will concern themselves primarily with the future of freshwater fishing and the quality of the water in lakes, rivers and streams from coast to coast.

Canadian Council of Resource Ministers 


\section{Pacific National Exhibition}

The British Columbia forest industry moved huge pieces of mobile equipment and 15,000 f.b.m. of logs into the Pacific National Exhibition to stage a demonstration of logging August 16-September 1.

An estimated 100,000 people saw the show, staged three times daily. The show featured rubbertired and track-mounted vehicles used to build forest roads, and to skid, lift and transport logs.

The equipment and logs were valued at $\$ 500,000$ The show was arranged by the Council of the Forest Industries of British Columbia, the Truck Loggers' Association and equipment dealers to inform the public of equipment and skills required in the forests. All equipment and hours of work were donated for the show.

The display was held in conjunction with loggers sports of axe, power saw and tree climbing events, part of the annual Festival of Forestry.

On site was a booth where information on logging careers was provided by professional staff of the industry, Canada Manpower, the Nanaimo Vocational School and the provincial Department of Labour.

All staff and equipment operators wore hard hats and high visibility orange-colour vests

On site were two Kenworth trucks and trailers. An on-off highway truck with eight-foot bunks was used in the show, while an off-highway model with a rated gross weight of 100 tons was on display only.

A Caterpillar D $8 \mathrm{H}$ carrying a winch, hydraulic angledozer and an operator's guard moved about the site as did a track-mounted Terex 82-40 dozer and a Tree Farmer C8 with power shift, winch and blade.

Choker cables and blocks from Wright's Canadian Ropes Ltd. were demonstrated at each show before a Caterpillar 988 log stacker, of 20-ton lift capacity, loaded the demonstration truck.

Off-loading was performed in a setting resembling a dry-land sorting yard.

Council of Forest Industries of B.C.

\section{Moose Hunting Restrictions}

Copies of the following letter to the Hon. George A. Snow, Minister of Lands \& Forests, Province of Nova Scotia, Halifax, N.S. were recently sent to Hon. G. I. Smith and other Cabinet Ministers, the Deputy Minister of Lands \& Forests, the N.S. Wildlife Federation, the N.S. Forest Technicians Association, and the Canadian Institute of Forestry.

Dear Mr. Snow:

The Nova Scotia Civil Service Association has learned with shock, of the ruling which prohibits employees of the Department of Lands \& Forests from making application for a licence to hunt moose.

The ruling has resulted in myriad speculation and charges. Speculation has it that Land \& Forest staff are somehow privy to the drawing which takes place to determine the names of those who shall be granted licences to hunt; charges include a designation of second class citizens, a charge which this Association deplores, denies and disassociates itself from entirely. In our opinion, there are no second class citizens in Nova Scotia. However, we do question any action or deed that denies to one group of citizens and taxpayers, a right that is granted to others

I have been directed by the Provincial Executive to ask in the strongest terms possible, that this ruling, repugnant to us and discriminatory to those to whom it applies, be rescinded in time to permit the members of the staff of the Department of Lands \& Forests to exercise the same rights and privileges as those extended to other Nova Scotians.

Yours truly,

T. A. Shiers,

Executive Secretary,

Nova Scotia Civil Service Association

\section{Totem Award for Canadian Forestry Service TV Spot}

The Totem Award for the top television spot announcement dealing with forest fire prevention in Canada was won by the Canadian Forestry Service at the annual Forestry Film Festival, conducted by the Federation of Canadian Forestry Associations at Vancouver in August.

Accepting the totem trophy on behalf of the Canadian Forestry Service is P. L. Northcott, Associate Director of the Vancouver Forest Products Laboratory, and A. P. Norton, Audio-Visual Officer with the Forestry Information Service, Ottawa. The presentation was made by Mrs. Cam Fleming, a festival judge.

Department of Fisheries and Forestry.

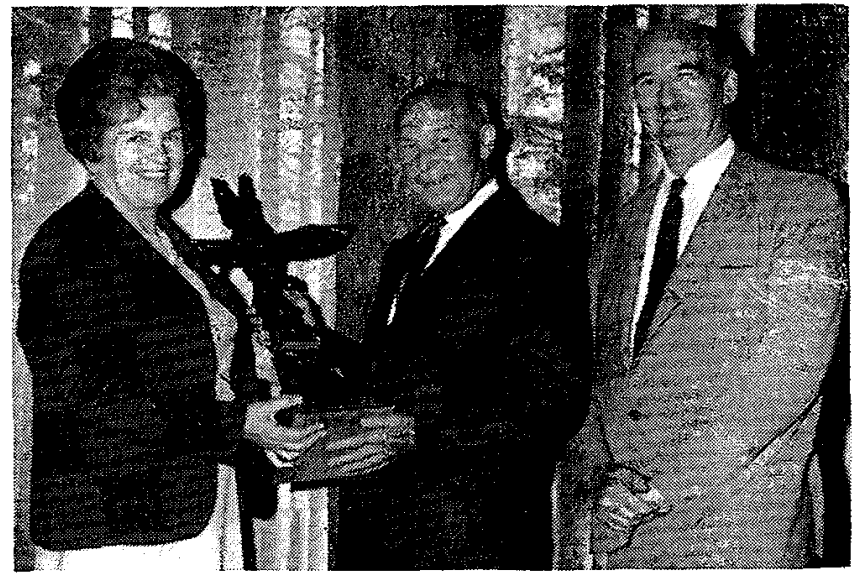

Hon. Mrs. Fleming, P. L. Northcott, A. P. Norton. Presentation of Totem Award. 


\section{International Union of Societies of Foresters}

Washington, D.C., August 20, 1969. - Professional foresters representing forestry societies from nine countries met August 18 and 19 in Washington, D.C. to organize the International Union of Societies of Foresters. The purpose of the Organizing Congress was to adopt a Constitution and Bylaws and formulate a program of future activities for the Union.

The increasing pace of advances in science, the mounting social and economic problems whose solutions involve the use and management of forest resources, the necessity of keeping forestry education abreast of employers' needs, and the increasing importance of international trade caused foresters to form this international organization. IUSF will provide a medium for the exchange of information and ideas, and for cooperation in working toward improved standards of forestry education worldwide. Members of the Union will be forestry societies which represent the forestry profession, not nations or employers.

Hosting the Congress was the Society of American Foresters. Dr. V. L. Harper presided. Delegates were: V. J. Palosuo of the Society of Finnish Foresters, Andre Metro of the Society of Friends and Ancient Students of the National School of Waters and Forests of Nancy (France), Morley Penistan of the Society of Foresters of Great Britain, Raul A. Catano of the Association of Mexican Professional Foresters, Chi Wu Wang of the Republic of China and W. D. Hagenstein of the Society of American Foresters.

Observers were: J. H. Teich for the Canadian Institute of Forestry, P. A. Houtermans of the Association of German Foresters, and Ingvar Ekholm of the Society of Swedish Foresters.

Organizations represented were the Food and Agriculture Organization of the United Nations, the International Union of Forestry Research Organizations, the International Society for Photogrammetry, the International Society of Tropical Ecology and the Organization of American States.

\section{Society of American Foresters.}

\section{Expansion in Nova Scotia}

Ten years ago it was stated that Nova Scotia could not support anymore pulp and paper mills. Since that time two large plants started operations.

Now, existing mills are planning expansion. It is reported that:

- Nova Scotia Pulp is reported as spending $\$ 60$ millions at Point Tupper for a newsprint output of 160.000 tons and to expand pulp making capacity from 130,000 to 175,000 tons annually.

- Scott Maritimes Pulp Ltd. is reported as planning a $\$ 3.5$-million expenditure to increase production.
- Bowaters Mersey is reported to be considering a $\$ 50$-million addition to double pulp-making operations at Liverpool using more low-grade material.

- Anil Hardboards Ltd. is reportedly studying the possibility of doubling present output.

An Atlantic Development Board report concluded that softwood harvest alone could be increased from 90-some to 130-million cubic feet annually.

Other provincial sources including Nova Scotia government officials claim that by utilization of all materials, better access, increased fire prevention and reforestation, and more forest industry coordination the output of Nova Scotia forest products could be, at least, doubled.

Halifax Chronicle - Herald.

\section{Highlights of 1968 Forest Insect and Disease Survey}

The spruce budworm was the dominant forest insect problem in Canada in 1968. Surveys in recent years have reflected a gradual increase in the incidence of budworm in susceptible forest stands and current developments suggest that major outbreaks may be developing in Ontario and the Maritimes. In the Maritimes there was a marked resurgence of populations, particularly in New Brunswick. Egg surveys have shown that, despite the chemical control program in 1968, potentially high populations persist over an area of some 3.6 million acres in the central part of that Province. In Ontario the situation follows much the same pattern. A spray program aimed at eliminating a potentially dangerous outbreak in the Burchell Lake area in the northwestern part of the Province did not completely attain its objective and potentially damaging populations still persist within the sprayed area. A number of small but hazardous outbreaks developed in the northeastern and central regions. In the west, infestations of spruce budworms still persist in the northern sections of Manitoba, Saskatchewan, Alberta and in the Northwest Territories.

The hemlock looper outbreak continued in Newfoundland. A spray program was carried out in 1968 and although reasonable control was obtained in treated areas, defoliation continued and caused extensive mortality of balsam fir. The Province and industry are faced with a large salvage operation and the situation may further deteriorate with the forecast of a spread and intensification of the outbreak in 1969. The rapid decline of infested stands is attributed in part to an earlier history of damage by the balsam woodly aphid.

The birch casebearer caused extensive damage to birch foliage throughout much of Quebec, the Maritimes and Newfoundland. Substantial extensions to the range of this introduced pest were recorded in Newfoundland and Quebec and in the 
latter Province damage in 1968 extended over an area of approximately 23,000 square miles.

The jack-pine budworm continued to be a major problem in natural and planted pine stands in central Canada. Moderate to severe defoliation was recorded over an area of some 7,800 square miles in northwestern Ontario and through adjacent areas in eastern Manitoba.

Defoliators of aspen constituted the major insect problem in the prairie regions. Severe defoliation by the large aspen tortrix was reported from many areas in southern Manitoba, Saskatchewan, Alberta and the Yukon Territory. In Alberta the Bruce spanworm was found in unusually high numbers, and some 7,000 square miles of trembling aspen in the west-central region were heavily infested with the forest tent caterpillar.

Other forest insects, although less extensive in scope, were of importance regionally. A serious outbreak of the spruce bark beetle developed in southwestern Alberta, a sharp increase in populations of the western hemlock looper and the green-striped forest looper caused concern in British Columbia, and defoliation by the saddled prominent was widespread in many hardwood stands in southern Ontario.

Unfavorable weather conditions caused damage in some regions and the following are worthy of note. Winter drying of conifers was severe along the eastern slopes of the Rocky Mountains and the foothills region of Alberta and over fairly extensive areas in Quebec and Ontario. Late frost damage was widespread in the Maritime Provinces and in Quebec; in the latter Province, freezing rains caused damage over two extensive areas. The effects of drought conditions in 1967 were conspicuous in southern British Columbia.

The Dutch elm disease continued its devastation of white elm in Ontario, Quebec and New Brunswick. In areas of southern Ontario where the disease has been present for 9 years or longer $69 \%$ of the trees are dead or diseased; the disease is causing heavy losses throughout most of the range of the host in Quebec; in New Brunswick, about $14 \%$ of the elms within the range of the disease are now infected.

New infection centers of Fomes annosus root rot were discovered in Ontario, and in British Columbia; the causal fungus was more common in immature, unthinned hemlock stands than previously believed. Since most of the commercial tree species in British Columbia are susceptible to stump infection, the fungus has a high potential for causing significant losses in thinned stands in that Region. Damage from armillaria root rot was reported from several regions. In Newfoundland, for example, the disease is considered to be one of the most important diseases of natural commercial forests. In the Alberta-Territories Region, the disease was detected throughout most areas and is believed to be responsible for the death of many tree species. Rhizina root rot caused the death of seedlings in slash-burn areas in British Columbia and, although losses were generally low, it appears that disease incidence will increase in areas where slash burning is carried out on contiguous areas in consecutive years. The causal fungus is known to occur in Ontario but no seedling mortality has been reported.

Scleroderris canker was observed in widely separated areas of Quebec and was associated with mortality in some jack and red pine plantations. The disease continued to cause extensive mortality to young planted pines in the eastern and central regions of Ontario. Surveys indicate that hypoxylon canker of poplar is a more serious problem in some parts of Ontario than previously realized. It is estimated that the volume of standing aspen killed or infected by the disease in the Maritime Provinces is in excess of 50 million cubic feet. Cytospora canker was responsible for severe damage to planted hybrid poplars in southern Alberta.

With confirmation of the occurrence of Peridermium harknessii in Ontario, the western gall rust is now known to occur from the Maritime Provinces to British Columbia. In the east, it is believed to cause more damage to hard pines than the eastern gall rust, Cronartium quercuum. Sweetfern blister rust was responsible for severe damage to exotic pines in the Maritimes Region and infections were heavy on jack pine over extensive areas of Ontario.

\section{Sex Attractants}

Two independent studies, one of which involves the sex life of insects, are being made to develop pest controls for forests by University of British Columbia and Simon Fraser University researchers.

Dr. John Borden at S.F.U. is investigating sex attractants of insects which damage bark and bore into trees.

His work and that of Dr. Bir Mullick at U.B.C. are supported in part by the Council of the Forest Industries of British Columbia. Support for the research efforts was recommended by the Council's Pest Control Committee which meets regularly with members of Provincial and Federal governments for exchange of information.

The objective of Dr. Borden's work is to develop an odour attractive to the insects and thus produce an effective and specific control method which would provide an acceptable alternative to conventional insecticides.

Dr. Borden's studies, commenced in 1967, are in collaboration with the Stanford Research Institude in California where there is allied research.

The research team has successfully isolated one of the compounds involved in attracting Douglas fir bark beetles.

In the laboratory, flying beetles reacted to the natural attractants by a sharp change in flight speed and, in the case of males, a cessation of flight.

Dr. Borden said he considers the results to date only a small step in determining the attractants, how to isolate them and how they can be synthesized for practical use.

At U.B.C., Federal Government bio-chemist and geneticist Dr. Bir Mullick is working in co-operation 
with Dean J. A. F. Gardiner's Faculty of Forestry.

He has found that some trees react to disease in a manner similar to that of the human body protecting its cells.

His studies concern the balsam woolly aphid, an accidentally imported pest which restricts its activities to species of true firs or "balsams". The insect is also selective among trees of the same species, choosing one and ignoring another nearby.

Dr. Mullick says he has no answer for the selectivity.

However, he has found that some trees develop a defence barrier around a disease area, killing up to 1,000 cells for each cell destroyed by the aphid's infection. The protective area forms in about 14 days and the pest dies.

Susceptible trees take 35 days to form the barrier, but this is sufficient time for the pest to continue feeding, to regenerate and therefore continue to infest other trees.

"If we could understand the resistance we could breed healthy trees", Dr. Mullick said. "But could the insect manipulate the resistance?"

Council of Forest Industries of B.C.

\section{Transformation radicale}

\section{du cours de foresterie}

La Faculté de foresterie et de géodésie de I'Université Laval inaugurera, dès septembre 1969, un nouveau programme en vue de la formation d'ingénieurs forestiers et d'arpenteurs-géomètres plus compétents et mieux préparés pour les grandes tâches qui les attendent.

A partir de cet automne, seuls les étudiants possédant un diplôme d'études collégiales (CEGEP) ou l'équivalent, comme le baccalauréat ès arts, etc. avec le profil requis en mathématiques, chimie et biologie, seront admis à la faculté comme étudiants réguliers.

Cette décision a été prise devant l'évolution rapide de la technique, des méthodes et des moyens de recherche, devant la transformation de notre milieu social et les modifications profondes de tout le système d'enseignement au Québec.

La faculté abandonnera donc dès cette année l'enseignement des matières de base et réorganisera ses programmes d'études traditionnels de façon à permettre à l'étudiant d'acquérir encore plus de connaissances dans le champ de concentration qu'il aura choisi: sciences forestières (aménagement et sylviculture, écologie et pédologie forestières, exploitation et utilisation des bois); sciences géodésiques (arpentage légal, géodésie, cartographie et photogrammétrie). II n'y aura plus d'années à la faculté.

\section{Crédits et options}

Pour l'obtention de l'un ou l'autre des deux diplômes qui sont actuellement dispensés par la facultés, l'étudiant devra obtenir un minimum de 150 crédits, dont un minimum de 120 provenant de cours obligatoires et un minimum de 30 provenant de cours à option. Parmi ces derniers, l'étudiant devra conserver un minimum de 20 crédits provenant des cours à option dispensés à la faculté dans son champ de concentration et 10 autres qu'il pourra acquérir dans n'importe lequel des départements ou facultés de l'université (droit, relations industrielles, sciences sociales, administration, etc.).

L'éventail des cours à option offert à l'étudiant lui permettra d'acquérir, dès le premier cycle de ses études universitaires conduisant au baccalauréat ès sciences appliquées, une spécialité dans un champ d'activité donné. Chacun de ces champs de concentration constituera pour l'étudiant intéressé à la recherche une porte ouverte à des études plus avancées conduisant à la maîtrise et au doctorat.

\section{Méthodes nouvelles d'enseignement}

L'étudiant progressera dans ses études suivant le système de promotion par matière et par trimestre. Pour l'aider dans son choix de cours et l'orienter dans son programme d'études suivant ses aspirations et ses goûts personnels, un conseiller lui sera attribué, choisi parmi les professeurs de carrière de la faculté.

En plus de ces modifications, chaque professeur a été invité à repenser ses méthodes d'enseignement. On assistera à une diminution de l'enseignement dit magistral qui sera remplacé, lorsque la matière enseignée le permettra, par des travaux dirigés, des colloques, des séminaires ou des exercices pratiques. Deux directeurs d'études sont chargés de l'organisation et de l'application des deux programmes d'études actuels conduisant au baccalauréat ès sciences appliquées avec mention en arpentage ou en génie forestier.

Le Papetier, août 1969.

\section{Le comité consultatif} de la foresterie

\section{remet son rapport}

\section{au ministère de l'Éducation}

Le comité consultatif de la foresterie vient de remettre un rapport au ministre de l'Education de la province de Québec.

Dans une première partie, le rapport traite des activités du secteur forestier au Québec et de la main-d'oeuvre utilisée. La seconde partie est consacrée à l'enseignement forestier, principalement aux niveaux secondaire et collégial. Voici quelquesunes des recommandations soumises par le comité consultatif:

- au niveau élémentaire, initier les enfants à la conservation forestière;

- au niveau secondaire court, prévoir des enseignements professionnels orientés vers toutes les branches des activités forestières pour les étudiants qui n'atteindront pas le niveau de métiers et orga- 
niser ces enseignements partout où les besoins d'une région l'exigeront;

- au niveau secondaire long, dispenser un enseignement spécialisé menant aux métiers de gardeforestier et aux métiers liés à l'industrie du sciage, classeur, scieur-classeur, affûteur;

- au niveau collégial, pour des raisons d'économie et d'efficacité, concentrer au C.E.G.E.P. de SteFoy l'enseignement de la troisième année du cours et offrir en dernière année trois options, soit l'aménagement, l'exploitation et la transformation.

Le comité suggère qu'il puisse dorénavant avoir pour tâche principale de contrôler la mise en place des programmes, d'en évaluer les résultats, de suggérer les modifications et surtout d'établir une collaboration soutenue et à part entière entre les responsables de l'enseignement forestier, les gouvernements, les universités et l'industrie forestière.

Forêt Conservation.

\section{Chatham N.B. Chipboard}

According to the Daily Commercial News and Building Record, Toronto, Ontario, the British Airscrew-Weyroc Company of London, England plans a \$13.5-million factory on the Miramichi River near Chatham, New Brunswick. The plant, for which construction start is said to be September 1969 and completion 1970 , will eventually produce 120 ,000 tons of wood chipboard a year. It is reported that the project is backed by the New Brunswick government with a $\$ 1,950,000$ grant, accelerated depreciation and a guarantee of a 15 year bond issue to finance part of the construction.

\section{Smooth Rock Lumber Mill}

A two million dollar specialized lumber mill is planned by Abitibi Paper Co. Ltd., construction to start in 1969 and be completed in 1970. The mill, to be at Smooth Rock Falls, where Abitibi already operates a kraft pulp mill, will employ 31 in the plant and 60 in forest operations.

Globe and Mail Business.

\section{MacMillan Rothesay Ltd.}

MacMillan Bloedel Ltd. of Vancouver and Feldmuehle AG of West Germany will form a company to take over the assests of Rothesay Paper Corp. Ltd. of Saint John.

The company, to be called MacMillan Rothesay Ltd., will be controlled by MacMillan Bloedel.

The companies also plan an immediate $\$ 35$-million expansion of the mill. The program involves installation of a newsprint machine with annual capacity of 180,000 tons, which will double present capacity. The machine should be in operation by January, 1971.

Feldmuehle recently increased its interest in Rothesay to 100 per cent from 42 per cent by buying the interests held by Fraser Cos. of Edmunston, N.B., and Genstar Ltd. of Montreal. It will sell its assets to the new company.

Feldmuehle is one of Europe's largest paper and paperboard producers. In addition to its Rothesay holdings, the company has a 37.5 per cent interest in Intercontinental Pulp Co. Ltd. of Vancouver.

Globe and Mail.

\section{Weldwood and Japanese}

\section{Firms Plan Mill}

Weldwood of Canada Ltd., Vancouver, a maker and distributor of plywood and related products, has signed an agreement in principle with two Japanese companies to build and operate an $\$ 80$ million bleached kraft pulp mill at Quesnel, B.C. Roger Montgomery, president of Weldwood, which is 75 per cent-owned by United States PlywoodChampion Paper Inc. of New York, says the agreement with Daishowa Paper Manufacturing Co., and Mirubeni-lida is only the first step in negotiations and that many details remain to be settled. A final contract is not expected until next fall.

Globe and Mail Business.

\section{Rayonier Canada}

Rayonier Canada (B.C.) Ltd., a unit of ITT Rayonier Inc. of New York, plans to spend about $\$ 2$ million to build a new woodroom at its pulp division at Woodfibre, B.C. The installation will be designed to handle small wood and small salvage logs that previously were considered too small to use economically. ITT Rayonier is controlled by International Telephone and Telegraph Corp. of New York.

Globe and Mail.

\section{Meetings}

\section{Forest Engineering Conference on Education}

A two-day Forest Engineering Conference on Education, to be held in conjunction with the winter meeting of the American Society of Agricultural Engineers, will convene December 8, 1969, in Chicago.

The conference is an outgrowth of the Michigan State Forest Engineering Conference held last September, according to $S$. J. Coughran, ASAE's PM55 conference program chairman.

Interest and questions generated during that meeting showed the need for a conference in which people in the manufacturing and consumer areas of forest engineering could exchange ideas with those of the education field.

The December conference will bring together several qualified participants from a wide geographical area who will formally discuss the more important aspects of educational needs for forest engineering. Ample time has also been scheduled during the two technical sessions for prepared and floor discussion.

The conference will convene at 1:00 p.m. Monday, December 8. First-session topics will include: the Forestry and Engineering Core Position, Needs of Forest Engineers in Manufacturing, and, Public and Private Forest Engineering Needs. 
The second session, on Tuesday morning, will explore Student Needs and Trends. The conference will conclude that morning with discussion and an open forum with all conference speakers.

Plans are also being made for presenting a forest film festival during the conference.

Headquarters for the conference will be in Chicago's Sherman House. Details of the complete program and reservation instructions will be announced at a later date.

ASAE release

\section{Guidance Counsellors Visit Swastika Forest District}

The Swastika District of the Ontario Department of Lands and Forests co-operated this summer with the Kirkland Lake District Chamber of Commerce and the Department of Education in hosting a group of Guidance Counsellors for a three-day intensive study of Department activities.

The Counsellors were attending a summer course to qualify as guidance specialists in Secondary Schools of the region. The students visited several businesses and firms including the Department of Lands and Forests, in July and August. Each teacher spent three days with several local establishments to learn the varieties of operations in the organizations.

At the Swastika District office the counsellors spent some time with each of the District Supervisors and then visited various operations in the field.

\section{National Science and Engineering Conference}

As a result of a $1 \frac{1}{2}$ day conference at Carleton University, July 31 - August 1, 1969, delegates of 55 societies representing about 100,000 members unanimously agreed to initiate the formation of a national scientific organization whose main goals will be to improve communication between each other, with government, and with the public. More than 100 delegates took this action following talks by various members of the government and participation in workshop discussions.

A steering committee was given a mandate to study goals and structures of a national organization and to make recommendations within six months to interested scientific societies. The work of the steering committee should lead to a Canadian organization representing a united voice of science to influence national science policy, to improve science public relationships, and to focus scientific resources on major problems such as pollution. The Institute membership will be kept informed on future progress.

V. J. Nordin

\section{Fisheries and Forestry Cuts}

Fisheries and Forestry Minister Jack Davis has announced a number of Departmental cuts for the next fiscal year, 1970-71. Reductions in staff and in spending on new facilities are being made.

Fisheries and Forestry staff will be cut back by 200 full-time employees and 350 seasonal employees. (The Department's staff presently comprises 4,300 full-time employees and 2,100 seasonal employees). Every effort will be made to find other jobs for those who are laid off.

Other plans to minimize expenditures include: postponent of all Departmental vessel replacements;

a $50 \%$ cutback in the Babine Lake salmon spawning project in B.C.;

financial assistance to certain universities for the promotion of co-operative producing and selling techniques among fishermen is to be terminated;

the fishing bounty will be discontinued.

Cutbacks, in total, are expected to save $\$ 12 \mathrm{mil}$ lion in 1970-71 in order not to exceed the planned overall Fisheries and Forestry Budget of $\$ 75$ million.

"This is an important economy," Mr. Davis said. "It will help us to streamline our operations for the longer term future. I hope it can also be realized without seriously affecting the quality of the services which our national Fisheries and Forestry people have been providing to the Canadian public over the years," he said.

Fisheries Information Section.

\section{B.C. Plywood Production}

British Columbia softwood plywood production was six per cent greater during the first six months of this year than during the same period of 1968, the Council of the Forest Industries of British Columbia reports.

Production was 934 million square feet $(3 / 8$-inch basis) during January-June, 1969, compared with 880 million square feet in the first six months of 1968.

The CFI reported that the total 1968 production was 1,807 million square feet.

Green veneer and softwood plywood are produced by 25 plants in British Columbia, using about seven per cent of the province's total log harvest.

Two new veneer plants are planned in north central B.C., one at Fort St. James and another at Prince George. The Fort St. James plant is scheduled for production by January and the other plant in May, 1970.

The Council said the plywood sector of the forest industry continues to be a major supplier of building products in Canada. Of the $\$ 152$ million worth of B.C. plywood sold in 1968, $74 \%$ was marketed in Canada. The balance was exported mainly to the United Kingdom and the European Common Market.

Council of Forest Industries B.C. 